\title{
I solation and characterization of flavone di-glucoside and acetoxyxanthone from the flowers of Bombex ceiba
}

\author{
S. C. Sati*, M aneesha D. Sati and A mita Sharma \\ Department of Chemistry, H.N.B. Garhwal University, Srinagar Garhwal- 246174 (Uttarakhand), INDIA \\ *Corresponding author. Sati_2009@rediff mail.com
}

Abstract: In present study two chemical constituents viz. Flavon 5,4' dimethoxy 8 methyl 7-O- $\beta$-D glucopyranoside5 '- $\beta$-D-glucopyranoside and xanthone 3-acetoxy-1-hydroxy-6-methoxy8-O- $\beta-D$-glucopyranosyl- $(1 \rightarrow 3)-\alpha-L$ rhamnopyranoside from the ethanolic extract of flowers of Bombex ceiba have been isolated and characterized.

Keywords: Flavone di-glucosid, Acetoxyxanthone, Bombex ceiba

\section{INTRODUCTION}

The plant Bombex ceiba belongs to the family Bombacaceae is a deciduous tree, abundantly found throughout India as a venue tree or wild in China and malasia. Most of the plants of this genus are medicinal and economically important. The developing buds of Bombex ceiba is an important vegetable of Garhwal hills. Decoction of dried flowers is given in fever, particularly in malaria. Gum collected from the stem of B ombex ceiba are commonly used in abdominal pains, aphrodisiac and digestive disorders .The fibers of the seeds (Kapok) commercially used for stuffing cushions and pillows. Wood used for boat and matchsticks (Gaur, 1999).

The present paper deals with isolation and characterization of flavone di-glucoside and 3-acetoxy xanthone from the alcoholic extract of the flowers of Bombex ceiba, with the help of chemical and spectral studies.

\section{MATERIAL AND METHODS}

Test material, extraction and isolation: The flowers of Bombex ceiba was collected from Badkot Chauras District Tehri Garhwal, Uttarakhand. The air-dried and coarsely powered flowers of the plant were defatted with light petroleum in a soxhlet. The defatted mass was exhaustively extracted repeatedly with $90 \%$ aqueous $\mathrm{EtOH}$, untill the extractive became colourless. All the extracts were mixed and concentrated under reduced pressure using rotatory vacuum evaporator.

The concentrated extract was adsorbed on silica gel and fractionated through column chromatography using the solvent system chloroform: methanol (97: 3). The polarity of solvent was gradually increased by addition of methanol. Repeated column chromatography afforded compounds 1 and 2 together with apigenin and kaemferol.
Melting points uncorrected, Column chromatography was carried out on silica gel (60-120) mesh. Merck, eluting solvent $\left(\mathrm{CHCl}_{3:} \mathrm{MeOH}\right)$. Ultra Violet (U.V.) was taken in $\mathrm{MeOH} .{ }^{1} \mathrm{H}-\mathrm{NMR}$ spectra were taken using tetramethyl silane (TMS) as internal standard and deuterated chloroform $\left(\mathrm{CDCl}_{3}\right)$ and deuterated methanol $\left(\mathrm{CD}_{3} \mathrm{OD}\right)$ as solvents, all the signals are expressed as values downfield from tetramethyl silane TMS.

\section{RESULTS AND DISCUSSION}

The ethanolic extract of flowers of Bombex ceiba on repeated column chromatography over silica gel afforded compounds 1 and compound 2 together with apigenin and kaemferol. The structure of apigenin and kaemferol was confirmed by their comparision with an authentic sample (tlc) and reported data of the compound (Mabry et al., 1970). The structure of compound 1 was identified as Flavon 5,4' dimethoxy 8 methyl 7-O- $\beta$ - D glucopyranoside- 5 ' $-\beta$-D-glucopyranoside and compound 2 as xanthone 3-Acetoxy-1-hydroxy-6-methoxy-8-O- $\beta$-D glucopyranosyl (1'!3)- $\alpha$ - L rhamnopyranosyl with the help of chemical and spectral studies.

Compound 1: It was obtained as crystalline solid from $\mathrm{MeOH}$ and its characterstics were recorded as follows:
Melting Point
$220--222^{\circ} \mathrm{C}$
Molecular Formula
Molecular Weight
$\mathrm{C}_{30} \mathrm{H}_{28} \mathrm{O}_{16}$

${ }^{1} \mathrm{H}-\mathrm{NMR}\left(\mathrm{CDCl}_{3}, 100 \mathrm{MHz}, \mathrm{\delta ppm}\right)$

$2.66(\mathrm{~d}, \mathrm{~J}=1.6 \mathrm{~Hz}), 3.49(\mathrm{~s}), 3.25(\mathrm{~s}), 7.70(\mathrm{~d}, \mathrm{~J}=8.4 \mathrm{~Hz})$, $6.38(\mathrm{~d}, \mathrm{~J}=7.5 \mathrm{~Hz}), 7.02(\mathrm{~d}, \mathrm{~J}=7.5 \mathrm{~Hz}), 7.29(\mathrm{~d}, \mathrm{~J}=1.5 \mathrm{~Hz})$, $5.45(\mathrm{~d}, \mathrm{~J}=6.8 \mathrm{~Hz}), 5.49(\mathrm{~d}, \mathrm{~J}=7.5 \mathrm{~Hz}), 5.42(\mathrm{~d}, \mathrm{~J}=6.8 \mathrm{~Hz}, \mathrm{C}-1$ ' anomeric proton), $4.98(\mathrm{~d}, \mathrm{~J}=5.8 \mathrm{~Hz}, \mathrm{C}-1 "), 3.65-4.72$ (sugar multiplet)

${ }^{13} \mathrm{C}-\mathrm{NMR}\left(\mathrm{CDCl}_{3} 150 \mathrm{MHz}, \delta \mathrm{ppm}\right)$

79.3 (C-2), 43.0 (C-3), 190.1(C-4) 162.8 (C-5), 110 (C-6), 163.5 (C-7), 99.7 (C-8), 127.9 (C-9), 115.7(C-10), 123.9(C- 
11), 113.6 (C-12), 141.1 (C-13), $147.0(\mathrm{C}-14), 41\left(-\mathrm{OCH}_{3}\right)$, $40.2\left(-\mathrm{OCH}_{3}\right), 20.9\left(-\mathrm{OCH}_{3}\right)$

A rabinopyranosyl: 101.9(C-1'), 73.1(C-2'), 76.0(C-3'), 69.9(C-4'), 76.0(C-5'), 69.4(C-6')

Glucopyranosyl: 103.1(C-1"), 73.1(C-2"), 75.5(C-3"), 69.3(C-4"), 75.0(C-5"), 60.3(C-6")

The compound 1 was found to be positive for coloration with methanolic $\mathrm{FeCl}_{3}$, Molish test and Shinoda test ( $\mathrm{Mg} / \mathrm{HCl}$ ) thereby indicating flavonoidal nature of compound. IR spectra of compound displayed absorption bands at 3302, 1665, 1622, 1505 showed presence of hydroxyl and carbonyl functions in the compound. The molecular formula of compound was calculated as $\mathrm{C}_{30} \mathrm{H}_{28} \mathrm{O}_{16}$ which correspond the molecular weight $644 \mathrm{amu}$,due to the presence of molecular ion peak at $\mathrm{m} / \mathrm{z} 644[\mathrm{~m}]^{+}, 645[\mathrm{M}+\mathrm{H}]^{+}, 675\left[\mathrm{M}+\mathrm{CH}_{3} \mathrm{OH}\right]$. Other fragment ion peaks appeared at $\mathrm{m} / \mathrm{z} 452[(\mathrm{M}+\mathrm{H}$ )$\left.^{+}-\left(\mathrm{OCH}_{3}+162\right)\right]$ and $273\left[(\mathrm{M}+\mathrm{H})^{+}-\left(\mathrm{OCH}_{3}+\mathrm{OH}+2 \times 162\right)\right]^{+}$ . The ${ }^{1} \mathrm{H}$ NMR spectrum of compound displayed two doublets at $\delta 6.38(\mathrm{~d}, \mathrm{~J}=7.5 \mathrm{~Hz}, \mathrm{C}-12)$ and $\delta 7.02(\mathrm{~d}$, $\mathrm{J}=7.5 \mathrm{~Hz}, \mathrm{C}-13)$ and one doublet of $1.6 \mathrm{~Hz}$ coupling constant appeared at $\delta 2.66(\mathrm{C}-3)$ assigned for flavonoidal proton. Adoublet of $8.4 \mathrm{~Hz}$ at $\delta 7.70$ ascribed to $\mathrm{C}-6$ of flavonoid. The position of two , $3 \mathrm{H}$ proton singlet at $\delta 3.49$ and $\delta 3.25$ assinged for two $\mathrm{OCH}_{3}$. The ${ }^{1} \mathrm{H}$ signals appeared at $\delta 3.60-5.4$ ascribes the sugear moiety in the molecule. The position of two doublets at $\delta$ $5.42(\mathrm{~d}, \mathrm{~J}=6.8 \mathrm{~Hz})$ and $\delta 4.98(\mathrm{~J}=7.5 \mathrm{~Hz})$ represents two anomeric sugars. The presence of two sugars were further in agreement with the FAB-MS data displayed peaks at $\mathrm{m} / \mathrm{z} 452$ and 273 arose by the loss of two sugar molecule from the molecular ion peak. All These values were in agreement with its ${ }^{13} \mathrm{C}$ NMR data. The coupling constant value of anomeric sugar showed $\beta$ configuration in both the sugar molecule. Compound when hydrolysed with $7 \%$ methanolic $\mathrm{HCl}$ furnished two glucose molecules (from PC and tlc). Methylation, methanolysis and partial hydrolytic studies revealed the position of both the sugar in different carbon. All these data were in agreement with the reported data of flavonoidal glycoside [3]. Hence compound was identified as Flavon 5,4' dimethoxy 8 methyl 7-O- $\beta$ - D glucopyranoside- 5'- $\beta$ Dglucopyranoside. (Fig.1)

Compound 2: It was obtainted as colourless crystalline solid from $\mathrm{MeOH}$ and its characterstics were recorded as follows:

M.P. $\quad: 196-198^{\circ} \mathrm{C}$

Molecular formula : $\mathrm{C}_{28} \mathrm{H}_{30} \mathrm{O}_{15}$

Molecular weight : 606

I.R. $\left(v_{\max }^{\mathrm{KBr}}\right) \mathrm{cm}^{-1}: 2995,3000,1640$

FAB MS (m/z):606[M] $]^{+}, 607[\mathrm{M}+\mathrm{H}]^{+}, 460[\mathrm{M}+\mathrm{H}-\mathrm{Rham}]^{+}$

$298[\mathrm{M}+\mathrm{H}-(\mathrm{rha}+\mathrm{glu})]^{+}, 255,209$

${ }^{1} \mathrm{H}$ NMR $\left(\mathrm{CDCl}_{3}, 100 \mathrm{MHz}, \mathrm{Oppm}\right)$

6.83(d,J=8.4Hz),7.68(s),7.24(s), 6.62( d, J = 8.4 Hz), 2.48 (s), 2.65 ( s ), 9.06 ( s ), glycone : $5.43(\mathrm{~d}, \mathrm{~J}=7.8 \mathrm{~Hz}), 5.2$ ( s), 3.5-4.9 ( sugar proton ).

${ }^{13} \mathrm{C} \mathrm{NMR} \mathrm{(CDCl} 150 \mathrm{M} \mathrm{Hz}$, 6ppm):

A glycone: 163.9(C-1), 117.6(C-2), 1473(C-3), 122.21(C-4), 125.4(C-5), 145(C- 6), 128.6(C-7), 163.3(C-8), 191.4(C-9), 18.4(C-10), 138.7(C-11), 116.3(C-12), 115.7(C-13), 115.4(C14), 176.0 $(\mathrm{C}=\mathrm{O}), 43.3(\mathrm{CH} 3), 56.3(\mathrm{OMe})$,

Glycone: 103.0 (C-1'), 73.6 (C-2'), 79.6(C-3'), 63.1(C-4'), 76.3(C-5'), 61.2(C-6').

Glycone: 101.9(C-1"), 73.4(C-2"), 77.4(C-3"), 69.9(C-4"), 60.9(C-5"), 18.5(C-6")

It gave green colouration with $\mathrm{FeCl}_{3}$ and also responded positive test with Molish reagent thereby indicating phenolic nature of the compound [Harborne,J.B. 1999]. IR spectrum of compound showed characteristic bands at 2995, 3000 and $1640 \mathrm{~cm}^{-1}$ for phenolic hydroxy and carbonyl groups . ${ }^{1} \mathrm{H}$ - NMR spectrum of the compound displayed two $1 \mathrm{H}$ proton singlets at $\delta 7.24$ and $\delta 7.68$ for C-5 and C-4 hydrogen, which confirmed the presence of xanthone skeleton in compound. Two doublets of $8.4 \mathrm{~Hz}$ coupling constant appeared at $\delta 6.83$ and $\delta 6.62$ showing an ortho coupling. Two upfield sharp singiets at $\delta 2.48$ and $\delta 2.65$ indcated the presence of two methoxy group in compound, whereas a weak singlet at $\delta 9.06$ were assigned for hydroxyl group. Two anomeric proton resonated at $\delta$ $5.43(\mathrm{~d}, \mathrm{~J}=7.8 \mathrm{~Hz})$ and $\delta 5.2(\mathrm{~s})$ with other sugar peaks appeared between $\delta 3.1-4.9$ assigned for 10 sugar protons. The molecular weight of compound was deduced as 606 amu which corresponding the molecular formula $\mathrm{C}_{28} \mathrm{H}_{30}$ $\mathrm{O}_{15}$, due to the presence of molecular ion peak at $\mathrm{m} / \mathrm{z} 607$ $[\mathrm{M}+\mathrm{H}]^{+}$.

The presence of these different groups were in agreement with the mass fragmentation of a compound as shown by its FAB-MS which furnished peaks at $\mathrm{m} / \mathrm{z} 460[\mathrm{M}+\mathrm{H}$ - Rham ${ }^{+}, 298[\mathrm{M}+\mathrm{H}-(\text { Rham+Glu })]^{+}, 255[\mathrm{M}-$ $\left.\left(2 \mathrm{Glu}+\mathrm{COCH}_{3}\right)\right]$ and $209\left[\mathrm{M}-\left(2 \mathrm{gly}+\mathrm{COCH}_{3}+\mathrm{OCH}_{3}\right)\right]$. The structure of glycone was further supported by its hydrolysis studies. Compound was hydrolyzed with $7 \%$ methanolic $\mathrm{HCl}$ for about 8 hours. It furnished an aglycone identified as 3-Acetoxy-1-hydroxy-6-methoxy xanthone from its reported data. The neutralized hydrolysate gave two sugars identified as glucose (PC, Rf value 0.18 ) and rhamnose (PC, Rf value 0.37). Compound 2 on partial hydrolysis yield one rhamnose (PC, Rf value 0.37 ) and one monoglycosidic aglycone. The prosapogenin on further $\mathrm{HOH}$ yield one xanthone as an aglycone (tlc) and glucose (PC, Rf) showed the sequential loss of sugars. The point of glycosidation was established by the ${ }^{13} \mathrm{C}$ NMR data of sugars which was fixed at C-3 of glucose with $\mathrm{C}-1$ of rhamnose .The configuration was found to be $\beta$ in glucose and $\alpha$ in rhamnose by the $\mathrm{J}$ value of anomeric sugar in its ${ }^{1} \mathrm{H}$-NMR spectrum.

These all values were compared with the reported data 


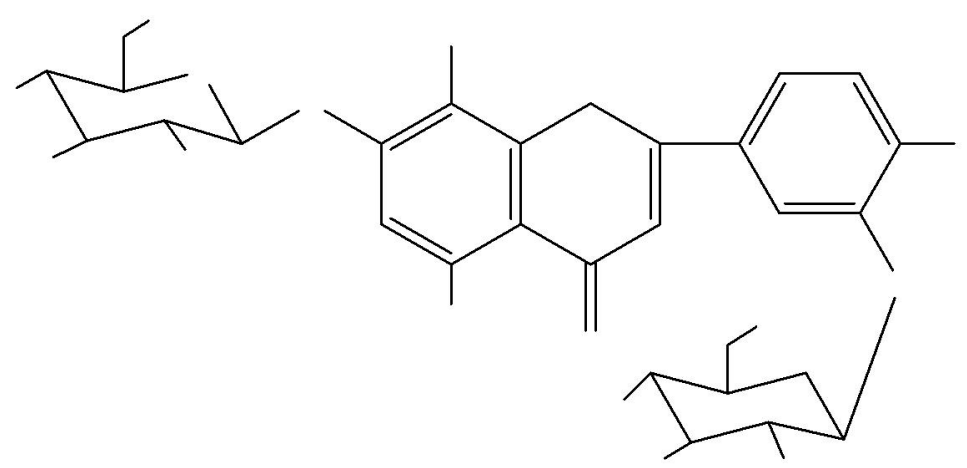

Fig. 1

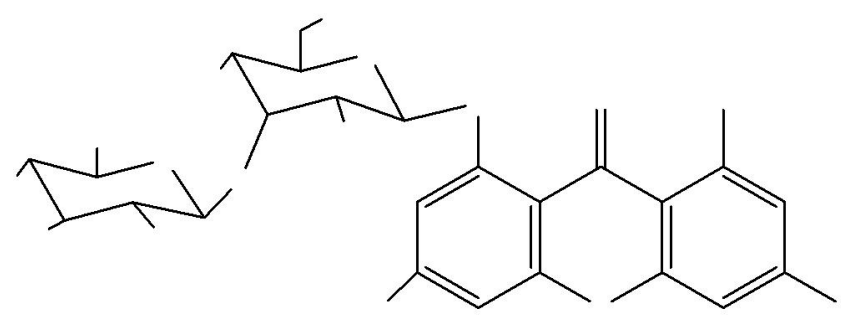

Fig. 2

of xanthone glycosides [Harborne,J.B. 1994]. Thus on the basis of spectral studies compound 2 was identified as xanthone 3-Acetoxy-1-hydroxy-6-methoxy-8-O- $\beta-\mathrm{D}$ glucopyranosyl-(1'!3)- $\alpha$-L-rhamnopyranoside (Fig.2).

\section{REFERENCES}

Gaur,R.D. (1999). Flora of District Garhwal (167-268). Trans Media, Srinagar, Garhwal.

Mabry,T. J., Markham, K.R. and Thomas,M.B.(1970). The
Systematic identification of flavonoids. Springer Verlag, Berlin, 41 (164): 268-270.

Emam, A. M., Elias,R., Moussa,A.M., Faure,R.L. Debrauwer and Balansar,G. (1998). Two flavonoid triglycosides from Buddleja madagascariensis. Phytochemistry, 48: 739742.

Harborne, J.B. and Baxter H. (1999). Handbook of natural flavonoids, VileyChichester, 2.

Harborne,J.B. and Grayer R.J. (1994). Flavonoids, Chapman and Hall London, 589. 